\title{
Japan imagined: popular culture, soft power, and Japan's changing image in Northeast and Southeast Asia*
}

\author{
NISSIM KADOSH OTMAZGIN
}

\begin{abstract}
Over the past two decades, Japan's popular culture has been massively disseminated and consumed throughout Northeast and Southeast Asia. A wide range of products, such as music, animation, comics, television programs, fashion magazines, and movies, have been endorsed by local popular culture markets and now constitute an integral part of the cultural lives of many young people in this region. These products not only introduce a multitude of consumption options, but also have an impact on the way young urban consumers imagine and think about Japan.

This paper examines the extent to which popular culture can change the perception of a country abroad. Based on questionnaire surveys conducted with university students from Hong Kong, Bangkok, and Seoul, it focuses on the appreciation shown to Japan's popular culture, and how it shapes young people's image of the country. The central argument presented is that exposure to Japanese popular culture disseminates new, favorable images, which modify the way the country is perceived. These images arouse feelings of affinity and a sense of proximity, but unlike the "soft power" argument, they are generational, implicit, inconsistent, and subject to different interpretations. As such, the practicality of generating state power in terms of authority or control is doubtful.
\end{abstract}

Keywords: Japan; popular culture; soft power; cultural consumption; image formation. 
想像上の日本：ポピュラー・カルチャー、ソフトパワー、北東 · 東南アジアにおける変わりつつある日本のイメージ

オトマズギン・ニシム

ここ20年ほどの間に日本のポップカルチャーは北東および東南アジア で広く浸透し、受け入れられるようになった。音楽、アニメ、コミッ ク、テレビ番組、ファッション誌、映画などおびただしい数の商品が 現地のポップカルチャー市場で提供され、若者の文化生活に不可欠な 要素となっている。これらの商品は多様な消費選択を可能にするだけ ではなく、都市部の若者が抱く日本のイメージにも影響を及ぼしてい る。本稿は、ポップカルチャーが他国に対する認識にどのような変化 をもたらすかを検証するものである。香港、バンコックおよびソウル の大学生を対象としたアンケートをもとに日本のポップカルチャーが 如何に評価され、現地の若者の日本のイメージがどう形成されるかを 調査した。その結果、日本のポップカルチャーに触れた若者の日本に 対するイメージは概して好意的であり、今までの認識を修正した新し いイメージが広がっている。その新しいイメージは親近感や地理的近 接性に基づくものであるが、いわゆる「ソフトパワー論」とは性格を 異にする。これらのイメージには世代的に差異があり、黙諾的でもあ る。一貫性がなく多角的な解釈が可能でもあるものに対し当局が取り 締まるとすればその必要性は疑問である。

\section{Introduction: Japan's cultural presence in East Asia}

Over the past two decades, Japan's popular culture has been massively disseminated and consumed throughout Northeast and Southeast Asia (hereafter "East Asia"). A wide range of products, such as music, animation, comics, television programs, fashion magazines, and films, have been endorsed by local popular culture markets, and they now constitute an integral part of the cultural lives of many young people in this region. ${ }^{1}$ The dissemination of Japan's popular culture has a special salience in the cultural geography of East Asia. This saliency is expressed both in the wide spectrum of products offered in the market as well as in their easy availability. Japanese popular culture products are abundantly offered for sale as CDs, DVDs, and VCDs in stores, sold by street vendors, heard from music players and on the radio, and seen on television, advertisement billboards, and in movie theaters. Although it is possible to find Japanese music, dramas, and fashion in other parts of the world, outside of East Asia they typically constitute a much smaller market.

Taking female Japanese pop music artists as an example, female stars (or rather "idols") such as Amuro Namie, Utada Hikaru, and 
Hamasaki Ayumi are probably known to the majority of youngsters in urban East Asia, but not in Europe, South America, and the Middle East. Japanese television dramas and variety programs have also become an integral part of East Asia's television scene. Japanese television dramas (such as Tokyo Love Story, Long Vacation, and Yamatonadeshiko), Japanese variety programs (such as TV Champion), various cooking shows, and especially Japanese animation (such as Doraemon, Tiger Mask, and Detective Conan) are regularly broadcast on public television and cable channels in Hong Kong, Singapore, Thailand, Malaysia, Indonesia, and, more recently, in Taiwan and South Korea.

The acceptance of Japan's popular culture in East Asia is especially noteworthy given Japan's imperialistic past. In spite of the suffering that Japan inflicted on its neighbors in the decades leading up to the end of World War II, and its attempts to utilize its culture as a means of control in its colonies, contemporary Japanese popular culture has been endorsed by the local cultural markets and affects the cultural lives of many people in East Asia, especially the young. Although people in East Asia today may not be completely ignorant of Japan's past wrongdoing and might still be critical of the Japanese government, they continue to buy animation and comics in their tens of millions, routinely watch Japanese-made television programs, and often listen to Japanese pop music.

The result is that in many cities in East Asia, young people are routinely exposed to images of Japan through cultural consumption. Through exposure to popular culture, these young people have been acquiring new images and ideas about Japan and a special fascination toward certain contemporary aspects of the country, gradually coming to associate Japan as home to a dynamic and prosperous cultural industry, rather than just an industrial superpower or an ex-military aggressor. This implies that the massive dissemination of popular culture not only introduces a multitude of consumption options, but has an impact on the way young urban consumers imagine and think about Japan.

At the same time, it is important to note that the flow of popular culture in East Asia is not unidirectional. A variety of other popular culture confluences - both global (American) and regional (Chinese, Korean) - have intensified rapidly in recent years, and Japan itself has become a diligent importer of popular culture from other parts of East Asia. South Korean television dramas, films, music, and fashions, for example, have gained immense popularity in Japan and in the wider East Asia region, creating the Korean Wave, or Hanryu , as it is known among fans (Chua and Iwabuchi 2008). In this sense, the Japanese case is not an isolated phenomenon; similar developments are taking place in other contexts with other popular cultures as well. 
Based on questionnaire surveys completed by undergraduate university students from Hong Kong, Bangkok, and Seoul, this study analyzes the appreciation shown to Japan's popular culture and the way it shapes young people's perceptions of Japan. The central argument presented is that exposure to and consumption of popular culture modifies the way Japan is perceived by the dissemination of new, favored images of the country. These images arouse feelings of affinity toward Japanese culture and society and create a sense of proximity. However, these feelings are also generational, implicit, inconsistent, and subject to different interpretations. As such, the practicality of generating political capital from them in terms of state authority or control - as the soft power argument implies - is limited. In other words, the emotions and behaviors aroused by the consumption of popular culture tend to be inconsistent and vary in their intensity so that their meaning cannot be read in any monolithic way. There is no transformation of national content, but rather the manifestation of emotions, genres, and representations associated with and labeled "Japanese".

The discussion starts by critically examining the notion of soft power and questioning its basic theoretical assumptions, as well as its explicit call for governments to wield culture as a political tool. The paper then moves on to discuss the results of the questionnaire survey, especially regarding how exposure to popular culture affects young people's perception of Japan and its history. The results show that respondents refuse to see any government or state power "politics" resulting from their cultural consumption, and that they are able to discern the difference between their appreciation of Japan's popular culture and their view of the politics and history of Japan. Finally, the paper introduces a more semantically plural approach to the way popular culture shapes a country's image abroad, and ends by outlining the implications of this on the state. It is proposed that emotions and behaviors aroused or encouraged by popular culture products - which cannot be read in any monolithic way - matter more than a straightforward transmission of national "content", values, or ideals.

\section{Japanese soft power in Asia?}

The soft power argument claims that the dissemination of one country's culture, ideals, and values into other countries provides the potential for political power. According to Joseph S. Nye (2004a: 15), who coined the term, "soft power" lies in the ability of a nation to entice, attract, and fascinate other countries and societies so that a country "may obtain the outcome it wants in world politics because other countries admiring its values, emulating its example, aspiring to its level of pros- 
perity and openness - want to follow it". Nye first used this concept to describe America's capabilities, but later also cited examples from Europe, Japan, India, and China (2004a: 73-98, 2004b).

In recent years, the soft power theory has been echoed by academic and popular discourses, which are fascinated by the possibilities emanating from the export of Japan's popular culture. Advocates repeatedly emphasize the economic benefits of cultural exports and stress its possible contribution to the nation's diplomacy. Governmental and journalistic reports routinely quote Nye's concept of soft power to encourage the state to intervene. One of the most publicized examples of the fascination over Japan's resources of soft power is journalist Douglas McGray's (2002) depiction of Japan's booming cultural innovation and lifestyle as "Gross National Cool" (GNC). According to McGray, Japan should put more emphasis on its cultural production power in order to boost its economy and increase its influence in the world. Like Nye's soft power argument, McGray's influential article has been frequently quoted in academic works, governmental reports, and in the print media - including, among others, Aoki (2004), Asahi Shimbun (1 January 2006), Daliot-Bul (2009), METI (2003), Nikkei Shimbun (2004), Sugiura (2008), Yamasaki and Tachioka (2006) - indicating the rising importance of popular culture in Japan's economy and diplomacy.

The soft power theory has had its share of criticism, and even Nye himself admits that he developed this term as a descriptive rather than an analytical concept (Nye 2008). As Brantly Womack (2005) argues, the problem with soft power is that it seems to be more of a penumbra or halo of hard power, rather than a coherent theory. In fact, soft power does not work in quite the way politicians envisage it. In one of my own papers (Otmazgin 2008), I argue that the impact of Japan's popular culture lies in shaping the region's cultural markets, but not in exerting local influence or in creating Japanese-dominated "spheres of influence". Peng Er Lan (2007) also shows that in spite of the Japanese government's attempts to wield the popularity of Japanese culture for its own diplomatic purposes, the dissemination of Japanese anime is essentially a market- and consumer-driven process. And Nakano (2008) observes that Japan, as a nation-state, does not seem to be winning Chinese consumers' hearts and minds.

The expansion and acceptance of Japan's popular culture in East Asia provides a good case study for critically re-examining the notion of soft power. Indeed, the dissemination of Japanese popular culture shows that there is a lot of "power" in the ability of a country's popular culture to penetrate nation-state boundaries, even in countries where there is anger and contempt toward the producing country. Moreover, 
popular culture products endorse certain characteristics that endow them with greater importance than other consumer products. These characteristics make the purchase of a piece of furniture, a car, or a television set, for example, different from buying a music $\mathrm{CD}$, watching a television drama, or reading a comic book. The difference is in the way cultural products comprise images that could potentially arouse strong feelings of proximity or rejection, as well as convey images that have a higher potential for shaping the "receiver's" individual and communal identity.

Yet the Japanese case equally suggests that the soft power argument may not be able to fully capture the dynamics of how people appropriate and conceive imported cultures, and what sort of political impact the transnational dissemination of popular culture can generate. Specifically, the questionnaire survey, which this study draws upon, contributes to the debate over soft power by questioning three of the basic theoretical assumptions of this theory.

First, ideas of soft power imply that images and narratives carry encoded meanings that can be read in a certain way; for example, that people who watch American movies and listen to American pop music eventually acquire (American) ideas about society, individualism, democracy, and liberalism through passive consumption (Nye 2004a: 1115). However, the analysis in this paper shows that people may read or consume popular culture without acquiring national narratives or political meanings that are supposedly embodied in the products, but rather develop their own interpretations of them. This is closely tied to the point that it is not only the transfer of content and ideas that is important, but also the emotions, images, and interpretations that arise from the consumption of popular culture. In other words, cultural commodities are likely to express a wide variety of ideas, emotions, and sensibilities. Their consumption might serve to disseminate images, articulate individual and subgroups' identifications, and introduce new obtainable lifestyles and aspirations to fulfill a wide range of social and personal purposes. However, these images tend to diversify through the process of consumption. They are not necessarily drawn from or articulated with any dominant ideology, and thus the probability of extracting political gains from this sort of cultural consumption is doubtful.

Second, the soft power argument also assumes that people are consistent in their attitude toward a country in the sense that once they change their attitude or image toward a certain aspect of the country, it automatically changes their perception of the country as a whole. In the case of popular culture, the assumption is that once they start to like a country's culture and lifestyle, they end up supporting its policy 
and its position in world affairs. For this reason, those who were exposed to American pop culture, according to Nye (2004a: 12), "want to partake in the good life, American-style". However, the case in East Asia shows that people are able to accept contradictory notions and harbor positive impressions alongside negative ones. Based on questionnaire surveys, my study reveals that they can accept the notion that Japan is both "good" and "bad". Rather than erasing historical memories and political disputes, young consumers have developed a more complex view of Japan, harboring positive images alongside negative historical recollections. As such, popular culture does not completely emend the appreciation shown to a country and remains limited in certain aspects.

Third, the soft power theory maintains that changing a country's image abroad is possible through an explicit, intentional process administered by the national government. The soft power theory stresses the diplomatic and political gains that can be achieved by utilizing a country's culture and ideals - for example, by constructing institutions that represent the country's culture and ideology (such as the Fulbright Program or the World Trade Organization in the case of the United States). According to Nye, soft power essentially reflects the ability of a country to indirectly frame the preferences of other countries and societies without firing a shot, as in: "If I can persuade you to want what I want, then I do not have to force you to act the way I want you to act." For this reason, Nye $(2004 a$ : $73-98,2004 b)$ calls on governments to use their soft power resources as an integral part of their foreign policy. However, as the present analysis shows, the newly emerging perception of Japan is the result of an unintended, inconsistent, and implicit process, which is also generationally limited. The admiration of contemporary aspects of Japanese society and culture is not the result of conscientious coercion on the part of the state, but rather is cultivated through free consumer choice. Consumers are not being dispossessed of their sense of national identity, and consuming products from other cultures does not conflict with their identification of being Korean, Chinese, or Thai. Therefore, the state can offer very limited guidance on how to interpret the meanings arising from cultural consumption.

In summary, the case of Japanese popular culture in East Asia underlines the problematic nature of the soft power argument and the need to develop a more nuanced explanation. Japan's popular culture has indeed established a footing in the cultural markets of the region, and is especially visible in urban areas. However, the soft power theory addresses neither the inclusive way in which imported cultures are being consumed nor the ability of people to distinguish between their cultural consumption and their political and historical views. 


\section{Survey design and results}

\subsection{Survey design}

This section presents an analysis based on questionnaire surveys conducted among 239 undergraduate university students of social sciences in Hong Kong (June 2004), Bangkok (February 2005), and Seoul (April 2005). ${ }^{2}$ The students surveyed did not belong to the Japanese studies program at their university, nor were they enrolled in courses related to Japanese history, culture, or language. Given the scale of the questionnaires (239 respondents), it is obviously not possible to make a statistical generalization for the vast East Asian region. Instead, the attempt here is to provide insights into the way youngsters in urban East Asia appreciate and relate to Japan's popular culture, and more particularly to examine the way in which the consumption of popular culture influences the way they think about Japan.

The surveys were conducted by the author, with the help of local assistants, at The Chinese University of Hong Kong with 57 students (31 female, 26 male), Thailand's Chulalongkorn University with 63 students (36 female, 27 male), and in Seoul with 119 students from Korea University and Sungkonghoe University (60 female, 59 male). The majority of respondents (185) were either born in the city where the survey was conducted (Hong Kong/Bangkok/Seoul) or had lived there for at least 5 years (see Table 1). Most of the students (227) were between the ages 18 to 22 (the oldest student in the sample was a 25 -year-old male student from Seoul).

Although the questions had a guiding principle, the respondents were encouraged to define and express their own opinions. The ques-

Table 1. Questionnaire surveys with university students in three cities.

\begin{tabular}{|c|c|c|c|c|}
\hline City & University & $\begin{array}{l}\text { Number of } \\
\text { interviewees } \\
(N=239)\end{array}$ & $\begin{array}{l}\text { Born or living } \\
\text { in Hong Kong/ } \\
\text { Bangkok/Seoul } \\
\text { (for at least } \\
5 \text { years) }\end{array}$ & Survey period \\
\hline Hong Kong & $\begin{array}{l}\text { Chinese } \\
\text { University of } \\
\text { Hong Kong }\end{array}$ & $\begin{array}{l}57 \\
(31 \mathrm{~F}, 17 \mathrm{M})\end{array}$ & 49 & May 2004 \\
\hline Bangkok & $\begin{array}{l}\text { Chulalongkorn } \\
\text { University }\end{array}$ & $\begin{array}{l}63 \\
(36 \mathrm{~F}, 27 \mathrm{M})\end{array}$ & 52 & January 2005 \\
\hline Seoul & $\begin{array}{l}\text { Korean } \\
\text { University, } \\
\text { Sungkonghoe } \\
\text { University }\end{array}$ & $\begin{array}{l}119 \\
(60 \mathrm{~F}, 59 \mathrm{M})\end{array}$ & 84 & April 2005 \\
\hline
\end{tabular}


tionnaire included 19 open questions and two multiple-choice parts. It inquired about the students' general cultural consumption patterns, and of Japanese culture in particular, as well as their attitudes and opinions regarding various aspects of Japan's society and state. The first part of the questionnaire included general questions regarding cultural consumption such as: "What kind of music do you listen to?"; "What kind of television programs do you watch?"; "What kind of films do you watch?". The second part specifically inquired about the consumption and appreciation of Japanese popular culture products, and included questions such as: "Do you watch Japanese television programs?"; "If yes, what kind of programs and how often?"; "Do you listen to Japanese music?". The third part included various questions about Japanese contemporary culture, society, and state, focusing on the subjective experiences of the interviewees. This part included questions such as: "How are Japanese popular culture products different from American, Chinese, or Korean popular culture products?"; "What do you think of Japan?"; "What kind of country is it?"; "What do you think of Japanese people?".

Hong Kong, Bangkok, and Seoul were chosen as representatives of today's East Asia's metropolitans. These cities are major junctions where a considerable amount of wealth is concentrated and where a diverse flow of culture overlaps with consumerism. Extensive economic growth during the last two decades has cultivated the emergence of large middle-class populations, which share employment, education, and spending characteristics (Funatsu and Torii 2002; Shiraishi 2006). However, several important differences between these cities exist. First, there are different levels of economic development in terms of GDP per capita. In Hong Kong and Seoul the GDP per capita is comparatively high - in 2004 (at the time of the survey) GDP per capita was USD 34,200 and USD 19,200, respectively - whereas in Bangkok it was lower, amounting to USD 8,100 in 2004 (CIA World Factbook 2005). This difference is important because the consumption of cultural commodities is closely tied to the evolution of a consumer society that stimulates demand for popular culture imports.

Second, there is a difference in how people in these cities view their historical encounters with Japan. In Hong Kong and Bangkok, historical animosity plays a very marginal role in contemporary relations with Japan. This is not the case in Seoul. In South Korea, there is a legacy of resentment toward Japan emanating from 36 years of Japanese colonization (1910-1945). This animosity has been kept alive and continues to sizzle under the country's education system and mass media. The Korean government, for its part, banned Japanese culture for most of the post-World War II period (Kobari 2005: 37-41). In this sense, 
Seoul is an important case to test popular culture's ability to overcome historical setbacks.

Third, there are communities from different ethnic backgrounds in these three cities. While in Hong Kong the overall population can be referred to as Chinese, this is not the case in Seoul and Bangkok (Asami 1998: 313-314; Chirot and Reid 1997: 75-98). Thus, this study examines reactions of consumers coming from different ethnic backgrounds in order to include "ethnicity" as a factor in this survey.

\subsection{Inclusive approach to cultural consumption}

In the first part of the survey, respondents were asked about their general cultural consumption preferences. The results strongly indicate that an overall majority of the students in Hong Kong, Bangkok, and Seoul do not maintain a singular cultural preference or possess narrow cultural consumption patterns. Rather, they hold a variety of different cultural preferences, simultaneously consuming American, Chinese, Japanese, Korean, and Thai popular cultures. In other words, there is no monolithic or dominant flow of popular culture, and youngsters have diverse preferences, jointly consuming both imported and local cultural products. This suggests that a confluence of various popular cultures has been gaining ground among youngsters in these cities, and that consumers are inclusive in their attitude, not seeing a contradiction in liking different cultures at the same time.

In the realm of music, for example, 61 of the 63 students in Bangkok said they listened to more than one type of music, 49 of the 61 students said they listened to both American and Thai music; and 26 of these 61 students also mentioned they liked to listen to Japanese pop music. (The remaining two students said they listened to only one type of music: one said he only listened to American hip-hop music, and the other said she only listened to Thai pop music.) The same pattern appeared in Seoul and Hong Kong. In Seoul, 114 of the 119 respondents said they listened to various types of music, comprising mostly Korean and American pop music, but also Japanese, Chinese, and classical music. (Two of the remaining students in Seoul said they only listened to Korean music, one said he only listened to European electronic music, one only to American jazz music, and one said he never listened to music.) And in Hong Kong, 54 of the 57 students said they usually listened to music from different sources, mostly Chinese, American, and Japanese. (The remaining three students said they only listened to Chinese music from Hong Kong or Taiwan.)

As for television, almost all the respondents in these three cities said that they watched various kinds of television programs, including Japa- 
nese and Korean television dramas, American reality shows, local entertainment shows, Japanese animation, and local news. In Bangkok, 27 of the 63 students said they liked to watch the popular television program TV Champion, which is a locally produced entertainment show based on a similar Japanese television program (the respondents knew that this show originally came from Japan). All of these 27 respondents also said that they liked to watch other television programs, such as Japanese and American dramas. In Seoul and Hong Kong, 169 of the 176 respondents stated that they watched more than one type of television program.

\subsection{Japan's "creative" popular culture}

The second part of the questionnaire specifically examined the consumers' appreciation of Japan's popular culture. The results show that Japanese popular cultural products have come to be widely appreciated. The respondents emphasized Japanese popular culture's high quality and advanced artistic level. Japanese music, television dramas, and animation were repeatedly described as "creative", "interesting", "funny", "of high quality", "artistically stimulating", and "special" (in comparison to American, Korean, or locally made cultural commodities). Many of the students thought that Japanese popular culture was differentiated from American or locally produced popular culture because it offered a new and fascinating set of products, which they found easy to like. According to a young female student from Bangkok, Japanese pop music melodies are much easier to memorize, and only require the song to be heard "once or twice". Another female student from Hong Kong said that Japanese music artists were much "cooler" and "cuter" than their Hong Kong counterparts. A male fan from Hong Kong thought that Japanese television dramas were "much closer to reality and deal with issues I can identify with, like young romance and aesthetics". Japanese animation was repeatedly described as a powerful medium that carried viewers away into a new imaginative world. According to a male student from Seoul, Japanese animation was "far better than any other in the market". Similarly, Japanese comics were thought to convey a high level of artistic innovation not found anywhere else.

\subsection{Physical similarities}

Approximately $20 \%$ of respondents in all three cities indicated that it was much easier for them to become a fan of a Japanese idol than an American idol, because his or her physical appearance and behavioral 
nuances resembled their own. Physical characteristics that Japanese and other East Asians share, such as the shape of the head and the hair type, eye color, height, etc., have made it easier for consumers to connect to these Asian idols. For example, one female student from Hong Kong mentioned that she liked Japanese fashion because "it is more colorful and joyful, and besides, we and the Japanese can share the same fashion because we have a similar body shape".

In this regard, physical similarities in the appearance of music and television artists help East Asians accept Japan's popular culture. Interestingly, it is physical similarities that create proximity and not any sort of "Asian" substance that ostensibly resonates with East Asian consumers. Indeed, when I asked respondents in these three cities to tell me what was "Asian" in Japanese popular culture, they again emphasized physical similarities, such as the eyes, hair, and body size, as well as familiar behavioral expressions, such as shyness and child-like excitement. Not a word was said about ostensibly common "Asian" cultural practices or shared values (such as the perception of the family, the primacy of the group, etc.). A student from Bangkok explained: "There must be something appealing in the way a young Japanese pop diva dresses like a child and not as an American sexy superstar [...] maybe it is because she has typical Asian hair and a high-pitched voice.".

In this sense, there is dialectic between "foreign" and "familiar" in East Asian people's understanding of Japanese pop culture. Here, people see something "familiar" about Japanese popular culture (physical resemblance), but at the same time find novelty in the fact that these products are both new and foreign in origin (and, moreover, "foreign" signifies products with high amusement value). In this case, it is not just the "foreignness" that is valued; it is the fact that it is both familiar and different at the same time.

\subsection{Not quite "faceless" pop culture}

In the questionnaires, the interviewees were easily able to recognize Japanese popular culture products and differentiate between them and others in the market, such as American or local. Many respondents, for example, were able to name a variety of local television dramas, animations, and cover songs based on Japanese originals. This suggests that Japanese popular culture products are not completely non-national, or "faceless". Indeed, there is nothing "Japanese" in animated characters like Hello Kitty, Doraemon, or Pokémon, ${ }^{3}$ and it is not possible to recognize any subliminal "Asian" cultural messages embedded in the products that should supposedly resonate with Asian consumers. 
At the same time, however, consumers are aware that popular culture products on the market come originally from Japan. Nevertheless, their "Japanese flavor" lies in the formation of a specific genre explicitly and implicitly associated with Japan, and which is recognizable and appreciated by consumers. The appreciation shown to Japanese cultural products, due to their quality and high artistic level, creates a recognizable genre of products associated with Japan, though consumers do not recognize any subliminal Japanese cultural messages beyond the similar physical appearance of music and television idols.

\subsection{The image of the Japanese state}

The majority of interviewees described Japan in the questionnaires as a "developed", "advanced", and "modern" country. The exposure and consumption of Japanese popular culture has additionally incited the interest of the young interviewees in other aspects of Japan. Many of the interviewees said that they like Japanese food, and almost all said they would like to visit Japan.

In one of the Hong Kong interviews, a young fan of Japanese pop music expressed her appreciation of Japan by saying that "we [Hong Kongers] can never be Americans, but maybe one day we can be like the Japanese". Her imagined Japan, as she later explained, was constructed through watching Japanese television dramas and Japanese animation movies. In another interview in Bangkok, three young amateur animators mentioned that they had learnt the Japanese language through watching animation and they visited Japan at least once a year to learn about new cultural trends. One of them even announced: "Tokyo is our cultural capital."

These responses show that popular culture products can create a positive perception of a country. Consumers associate popular culture products, or genres of products, with Japan regardless of where these products were manufactured, how they got them, or if they really embodied Japanese traditions or values. For example, the animated characters Hello Kitty, Doraemon, and Pokémon do not look Japanese in any objective way. However, they are identified as Japanese because they represent a specific genre of animated products associated with Japan.

\subsection{History and popular culture}

The responses to the questionnaires provided some interesting insights into the interviewees' perceptions of Japan from a historical point of view. Japan's occupation period seems to play a very marginal role, if 
any, in the way the youngsters in Hong Kong and Bangkok perceive Japan. Only 7 out of 120 interviewees in these two cities briefly mentioned the war and the occupation period in descriptions of how they perceived Japan. Even though the invasion of the Japanese army of Hong Kong in December 1941 resulted in the destruction of large parts of the city and created approximately 600,000 refugees (i.e., about half the city's population) (Snow 2003: 53-89), Japan is perceived very positively. In Thailand, too, Japan's wartime atrocities are largely overlooked. According to Ubonrat Siriyuvasak (2004: 184), "if a teenager were asked about the anti-Japanese goods campaign of 1972, he or she would probably be unable to answer. Even fewer [older people] would remember the Japanese imperial military aggression that began on 8 December 1941, in which Japan took over Thailand."

The results from Seoul, however, were very different. Approximately two-thirds of the interviewees (61 out of 119) mentioned Japan's wartime actions and consequential responsibilities in their descriptions of Japan. The results from Seoul probably emanate from South Korea's trauma of 36 years of Japanese colonization, a trauma that has been kept alive and nurtured by the country's education system, mass media, and successive nationalistic governments. Reminders of the continued anger toward imperialistic Japan are occasionally displayed in antiJapanese demonstrations in South Korea, usually following controversies over visits to Yasukuni Shrine by Japan's leaders, or after the publication of new history textbooks in Japan (Kobari 2005: 38-41).

At the same time, questionnaire responses from Seoul showed that there is a strong current of ambivalence toward Japan. Most students chose to describe Japan in both positive and negative terms, differentiating their criticism of the Japanese state from their admiration of contemporary aspects of Japanese society and culture. In the multiplechoice part of the questionnaires, 24 out of 119 interviewees in Seoul chose to define their attitude toward Japan as both "somehow negative" and "somehow positive". One university student explained: "Most Japanese people are kind, but toward their government I am very negative [...] their policy toward Korea is very bad." Another revealed that, "I like Japanese culture and have Japanese friends, but I hate their right-wing government!" And her friend elaborated: "I like their fashion, music, and movies, but sometimes they make me mad because of the way they treat history."

These responses clearly show that there is a fundamental differentiation between the way these students relate to the Japanese state on the one hand, and their appreciation of aspects of Japanese society and culture on the other. In spite of the fact that historical and political controversies are kept high on the national agenda and continue to 
influence how young people view Japan, they do not influence young peoples' attitudes toward Japanese popular culture. It is apparent from the questionnaires in Seoul that although youngsters might remain politicized by the politics of memory (war, textbooks, etc.), they refuse to see any state-run politics in their affection for popular culture.

In other words, there is a juxtaposition of positive and negative attitudes toward Japan expressed by the same people on different issues. This implies that the youngsters in Seoul are able to harbor mixed feelings of both anger and resentment toward Japan while simultaneously liking its culture and expressing admiration for its achievements. This is why the audience reception of popular culture should not be seen in any monolithic or essentialist manner. Rather, it is a complex process of images translating into perceptions and sensibilities that are open to different readings.

\section{Re-imagining the Japanese state}

The results of the questionnaire survey strongly indicate that the dissemination of popular culture has been changing Japan's image in East Asia. For respondents of the survey, Japan is not only an ex-militaristic aggressor, but also a developed country with a fascinating contemporary culture and lifestyle. These youngsters have come to endorse the notion of Japan as being a "developed", "advanced", and "modern" country, as well as a producer of high-value cultural products. The consumption of Japanese popular culture does not stimulate allegations of "cultural imperialism", allegations that are often leveled at America. ${ }^{4}$ The appealing power of Japanese culture is seen as the non-nationalistic side of the country, reflecting its positive and friendlier sides.

The results in South Korea are especially noteworthy as they show that when it comes to history young Koreans might accept the conventional national interpretation provided by the state and the mass media regarding South Korea's relations with Japan. However, they develop their own appreciation when it comes to their personal consumption of Japan's contemporary culture and their own attitude toward that culture.

From a wider theoretical perspective, the survey results support the argument that popular culture has the potential to shape the perception of a country abroad by adding new layers to its image. The dissemination of popular culture creates a variety of new images of the "producer", which the consumer often identifies with. This is similar to the reflection of America and "the American way of life" in Hollywoodproduced films, which viewers sometimes identify with after watching. This is because popular culture works as a sort of reporting, providing 
representations of the country to outside audiences. It is effective in conveying and transferring images and representations, and in drawing and constituting people's private lives in the shape of fantasies, emotions, and lifestyles.

In other words, popular culture evokes an emotional bond or a personal relationship between the product or the service and the producing country. In this way, listening to music, watching a film or television drama, or playing a video game, becomes part of a leisure activity that might build new circles of allegiance. In the long term, this might encourage dialogue and cultivate an atmosphere of affinity among individuals based on a shared experience of the consumption of the same genre of popular culture products. Engaging in these practices might also indicate that there is a conscious attempt to set apart the official national interpretation provided by the state and develop new perceptions and preferences based on cultural consumption.

However, the sense of yearning for a particular country evoked through the consumption of cultural commodities is not a monolithic process but one that constructs a complex picture that is open to different interpretations. Insofar it is a process that cannot be explicitly wielded for a generation of support for a certain country. The state should thus refrain from using business-like methods to promote its image abroad so that a country can be attributed, or equipped, with the national qualities and characteristics it desires. The diplomatic course of cultural exports should be left solely to consumers to determine, as governmental attempts to wield political benefits often prove futile, if not harmful. In popular culture, state-run institutions work much less efficiently than the forces working outside the domain of centralized control, and market forces are much more powerful in leading consumers' tastes and priorities.

Nissim Otmazgin is Lecturer at the Department of East Asian Studies and Research Fellow at the Harry S. Truman Research Institute for the Advancement of Peace at the Hebrew University of Jerusalem. His research interests include cultural industry and cultural policy in Japan and South Korea as well as popular culture and regionalization in East and Southeast Asia. He holds a PhD from the Graduate School of Asian and African Area Studies, Kyoto University. He is the editor (together with Eyal Ben-Ari) of "Popular Culture and the State in East and Southeast Asia" (Routledge 2011) and "Popular Culture Co-production and Collaboration in East and Southeast Asia" (National University of Singapore Press, 2012). He has published extensively and is a member of the Association for Asian Studies and the European Association for Japanese Studies. 


\section{Notes}

* An earlier version of this paper was presented at the VFJS Annual Conference on "Cultural Power Japan", held at Goethe University Frankfurt, Germany, on 26-28 November 2010. The author wishes to thank Axel Klein and two anonymous reviewers for their helpful comments on an earlier version of this paper.

1. The proliferation of Japanese popular culture abroad has been well documented in the available literature, especially in anthropology and cultural studies, though not in political science and economic studies. Noteworthy studies which provide substantial testimony for the presence of Japanese popular culture overseas include Allison (2006), Ishii (2001), Iwabuchi (2002, 2004), Martinez (1998), Mōri (2004), Ötake and Hosokawa (1998), Shiraishi (2000), and Treat (1996).

2. The questionnaires were conducted with the help of Dr. Ubonrat Siriyuvasak (Chulalongkorn University) and Dr. Shin Hyun Joon (Sungkonghoe University). I am grateful for their assistance.

3. These three characters became extremely successful abroad. Hello Kitty is a catlike animated character that drives an empire worth USD 3 billion in global sales every year. Its revenues all come from licensing other companies $(12,000-$ 15,000 licenses a year) to use Hello Kitty's likeness. Doraemon is a robot-cat animated caricature that made its first print appearance in the 1970s and soon became an all-time hit abroad, especially in East Asia. Royalties connected with Doraemon merchandizing between 1979 and 1994 totaled USD 153 million. As of March 2004, Pokémon (poketto monsutā) had generated USD 2.3 trillion in sales in at least 67 countries worldwide.

4. In short, the cultural imperialism theory argues that there is a domination of cultural flows carried through media from the west to the rest, resulting in the destruction of local culture and in cultural homogenization. For the cultural imperialism theory and its critics, see Herman and McChensey (1997) and Tomlinson (1991).

\section{References}

Allison, Anne. 2006. Millennial monsters: Japanese toys and the global imagination. Berkeley \& Los Angeles: University of California Press.

Aoki, Tamotsu. 2004. Toward multilayered strength in the "cool" culture. Gaikō Forum 4 (2). 8-16.

Asahi Shimbun. 1 January 2006. 1-3.

Asami, Yasuhito. 1998. Chūkansō no zōdai to seiji ishiki no henka [The enlargement of the middle class and changes in its political consciousness]. In Toshio Tasaka (ed.), Ajia no daitoshi: Bankoku [Asia's big cities: Bangkok], 305-328. Tokyo: Nihon Hyōronsha.

Chirot, Daniel \& Anthony Reid (eds.). 1997. Essential outsiders: Chinese and Jews in the modern transformation of Southeast Asia and Western Europe. Seattle \& London: The University of Washington Press.

Chua, Beng Huat \& Kōichi Iwabuchi (eds.). 2008. East Asian pop culture: Analyzing the Korean Wave. Hong Kong: Hong Kong University Press.

CIA World Factbook. 2005. https://www.cia.gov/library/publications/the-worldfactbook/ (last accessed 10 July 2009).

Daliot-Bul, Michal. 2009. Japan brand strategy: The taming of "Cool Japan" and the challenges of cultural planning in a postmodern age. Social Science Japan Journal 12 (2). $247-266$. 
Funatsu, Tsuruyo \& Takashi Torii. 2002. Ajia chūkansō no tokushitsu to seiji shikō: "Chūkansō genshō" no imi suru mono [Features and politics of Asian middle classes: What are the implications of "the phenomena of Asian classes"?]. In Tamio Hattori, Tsuruyo Funatsu \& Takashi Torii (eds.), Ajia chūkansō no seisei to tokushitsu [The emergence and features of the Asian middle classes], 261276. Tokyo: Ajia Keizai Kenkyūsho.

Herman, E. S. \& R. W. McChesney. 1997. Global media: The new missionaries of global capitalism. London: Cassell.

Ishii, Ken'ichi. 2001. Higashi Ajia no Nihon taishū bunka [Japanese mass culture in East Asia]. Tokyo: Sōsōsha.

Iwabuchi, Kōichi. 2002. Recentering globalization: Popular culture and Japanese transnationalism. Durham, NC: Duke University Press.

Iwabuchi, Kōichi (ed.). 2004. Feeling Asian modernities: Transnational consumption of Japanese TV dramas. Hong Kong: University of Hong Kong Press.

Kobari, Susumu. 2005. Kankoku ni okeru Tainichi rekishi Ninshiki mondai [Problems in the historical perception of Japan in South Korea]. Kokusaimondai 549 (December). 21-45.

Martinez, Dolores P. (ed.). 1998. The worlds of Japanese popular culture: Gender, shifting boundaries and global cultures. Hong Kong: Cambridge University Press.

McGray, Douglas. 2002. Japan's gross national cool. Foreign Policy (May-June). 44-54.

METI (Ministry of Economy, Trade, and Industry). 2003. Chūkan torimatome [Midterm report]. Tokyo: METI, International Strategy Study Group.

Mōri, Yoshitaka (ed.). 2004. Nisshiki kanryū: Fuyu no Sonata to Nikkan Taishū bunka no genzai [Japanese style, Korean boom: Winter Sonata and current Japanese-Korean mass cultural relations]. Tokyo: Serika Shobō.

Nakano, Yoshiko. 2008. Shared memories: Japanese pop culture in China. In Yasushi Watanabe \& David L. McConnell (eds.), Soft power superpowers: Cultural and national assets of Japan and the United States, 111-127. New York: M. E. Sharpe.

Nikkei Shimbun. 2004. Nihon poppu karuchā [Japan's pop culture]. 5 January4 February. 1-3.

Nye, S. Joseph Jr. 2004a. Soft power: The means to success in world politics. New York: Public Affairs.

Nye, S. Joseph Jr. 2004b. Nihon no sofuto pawā sono genkai to kanōsei [Japan's soft power: Its limits and possibilities]. Gaikō Föramu 191 (June). 12-15.

Nye, S. Joseph Jr. 2008. Foreword. In Yasushi Watanabe \& David McConnell (eds.), Soft power superpowers: Cultural assets of Japan and the United States, ix-xiv. New York: M. E. Sharpe.

Ōtake, Akiko \& Shūhei Hosokawa. 1998. Karaoke in East Asia: Modernization, Japanization, or Asianization. In Tōru Mitsui \& Shūhei Hosokawa (eds.), Karaoke around the world: Global technology, local singing, 178-201. London: Routledge.

Otmazgin, K. Nissim. 2008. Contesting soft power: Japanese popular culture in East and Southeast Asia. International Relations of the Asia Pacific 8 (1). 73-101.

Peng, Er Lan. 2007. Japan's quest for "soft power": Attraction and limitation. East Asia 24. 349-363.

Shiraishi, Saya. 2000. Doraemon goes abroad. In Timothy J. Craig (ed.), Japan pop! Inside the world of Japanese popular culture, 234-272. New York: M. E Sharpe.

Shiraishi, Takashi. 2006. The third wave: Southeast Asia and middle-class formation in the making of a region. In Peter Katzenstein \& Takashi Shiraishi (eds.), Beyond Japan: The dynamics of East Asian regionalism, 237-271. Ithaca, NY: Cornell University Press. 
Siriyuvasak, Ubonrat. 2004. Popular culture and youth consumption: Modernity, identity and social transformation. In Koichi Iwabuchi (ed.), Feeling Asian modernities: Transnational consumption of Japanese television dramas, 177-202. Hong Kong: Hong Kong University Press.

Snow, Philip. 2003. The fall of Hong Kong: Britain, China, and the Japanese occupation. Hong Kong: Yale University Press.

Sugiura, Tsutomu. 2008. Japan's creative industries: Culture as a source of soft power in the industrial sector. In Yasushi Watanabe \& David L. McConnell (ed.), Soft power superpowers: Cultural and national assets of Japan and the United States, 128-153. New York: M. E. Sharpe.

Tomlinson, J. 1991. Cultural imperialism: A critical introduction. London: Continuum.

Treat, John W. 1996. Contemporary Japan and popular culture. London: Curzon.

Womack, Brantly. 2005. Dancing alone: A hard look at soft power. The Asia-Pacific Journal: Japan Focus 16 November. http://japanfocus.org/-Brantly-Womack/1975 (last accessed 12 July 2011).

Yamasaki, Shigeo \& Hiroshi Tachioka (eds.). 2006. Eizō kontentsu sangyō no seisaku to keiei [The policy and management of the image-content industries]. Tokyo: Chūōkeizasha. 
